\title{
Sensitive electrogenerated chemiluminescence peptide-based biosensor for the determination of troponin I with gold nanoparticles amplification
}

\author{
Meng Shan • Min Li • Xiaoying Qiu • Honglan Qi • \\ Qiang Gao $\cdot$ Chengxiao Zhang
}

Published online: 24 October 2013

(C) The Author(s) 2013. This article is published with open access at Springerlink.com

\begin{abstract}
A sensitive electrogenerated chemiluminescence (ECL) peptide-based biosensor was fabricated for the determination of troponin I ( TnI) by employing gold nanoparticles as amplification platform. Two specific peptides including peptidel with a sequence of CFYSHSFHENWPS and peptide2 with a sequence of FYSHSFHENWPSK were employed as capture peptide and report peptide, respectively. The peptide 2 was labeled with ruthenium bis(2,2'-bipyridine) (2,2'-bipyridine-4,4'-dicarboxylic acid)- $N$-hydroxysuccinimide ester ( $\mathrm{Ru}(\mathrm{bpy})_{2}$ (dcbpy)NHS) at $\mathrm{NH}_{2}$-containing lysine via acylation reaction and utilized as the ECL probe. Gold nanoparticles were electrodeposited onto gold electrode and used as an amplification platform. The peptide-based biosensor was fabricated by self-assembling peptide 1 onto the surface of gold nanoparticles-modified gold electrode through a thiolcontaining cysteine at the end of the peptide1. When the biosensor reacted with target TnI, and then incubated with the ECL probe, a strong ECL response was electrochemically generated. The ECL intensity is directly proportional to the logarithm of the concentration of $\mathrm{TnI}$ in the range from 1 to $300 \mathrm{pg} / \mathrm{mL}$. The biosensor employing gold nanoparticles as amplification platform shows high sensitivity for the detection of TnI with a detection limit of $0.4 \mathrm{pg} / \mathrm{mL}(S / N=3)$. Moreover, the biosensor is successfully applied to analysis of $\mathrm{TnI}$ in human serum sample. This work demonstrates that the combination of a highly binding peptide with nanoparticle
\end{abstract}

Electronic supplementary material The online version of this article (doi:10.1007/s13404-013-0113-x) contains supplementary material, which is available to authorized users.

M. Shan $\cdot$ M. Li $\cdot$ X. Qiu $\cdot$ H. Qi $(\triangle) \cdot$ Q. Gao $\cdot$ C. Zhang $(\triangle)$ Key Laboratory of Analytical Chemistry for Life Science of Shaanxi Province, School of Chemistry and Chemical Engineering, Shaanxi Normal University, Xi'an 710062, People's Republic of China e-mail: honglanqi@snnu.edu.cn

e-mail: cxzhang@snnu.edu.cn amplification is a great promising approach for the design of ECL biosensor.

Keywords Electrogenerated chemiluminescence · Gold nanoparticles $\cdot$ Peptide $\cdot$ Troponin I

\section{Introduction}

Acute myocardial infarction is a major cause of human death and responsible for one third of deaths in the world. Measurement of cardiac markers is critical in assisting the diagnosis of acute myocardial infarction [1,2]. Cardiac troponin I $(\mathrm{TnI})$, with a molecular weight of $24 \mathrm{kDa}$, a part of the troponin complex that is present in cardiac muscle tissues, has been known as a reliable biomarker of cardiac muscle tissue injury and was widely used in the early diagnosis of acute myocardial infarction [3, 4]. The concentration of TnI in blood rises rapidly within 4-6 h after the onset of an acute myocardial infarction and reaches to the maximum at approximately $12 \mathrm{~h}$. After 6-8 days, the TnI level returns to normal, and thus, the concentration of $\mathrm{TnI}$ in blood can provide a long diagnostic window for detecting cardiac injury [3]. A variety of methods such as colorimetric [5], electrochemical [2, $3]$, fluorescent [6, 7], and chemiluminescence [8] methods have been developed to determine TnI. Despite the extensive development of these methods, the major limitation in currently used methods for the determination of TnI assays is low sensitivity at the time of a patient's presentation, owing to a delayed increase in circulating levels of cardiac troponin [2]. Therefore, it is still a critical demand on sensitive and specific methods for the determination of TnI, especially in the pointof-care applications.

Electrogenerated chemiluminescence (also called electrochemiluminescence and abbreviated ECL) method 
has attracted considerable interest due to its high sensitivity, rapidity, easy controllability, and wide dynamic range $[9,10]$. Several ECL methods have been developed for the determination of TnI [11-15]. Cui designed ECL immunosensor for the detection of human cardiac troponin I by using luminol [11] and $N$-(aminobutyl)- $N$-(ethylisoluminol) [12] -functionalized gold nanoparticles as labels. Smith developed an ECL immunoassay for detection of rat $\mathrm{TnI}$ in serum [13]. The commonly used ECL immunoassays are normally conducted by employing antibodies as molecular recognition elements. However, the antibody drawbacks associated with the production and stability. Short linear binding peptides, which are obtained using phage display, have received considerable interest in protein analysis due to the advantages, such as stable, resistant to harsh environments, and more amenable to engineering at the molecular level than antibodies [16]. Recently, Park et al. reported a new peptide (FYSHSFHENWPS) that selectively bound to TnI with a disassociation constant of the complex in nanomolar level [17]. We developed two homogeneous ECL peptide-based methods for the determination of $\mathrm{TnI}$ using this peptide as a molecular recognition element $[14,15]$. In previously work [14], one peptide (FYSHSFHENWPSK), as a molecular recognition element, was labeled with ruthenium complex through $\mathrm{NH}_{2}$-containing lysine on the peptide via acylation reaction and utilized as an ECL probe. In the presence of TnI, a decrease in ECL signal was observed upon the binding event between the ECL probe and target TnI. The binding of small peptide with large target protein results in a sensitive ECL detection of protein compared with homogeneous immunoassay employing antibody as recognition element. However, the detection limit of previously homogeneous ECL method $\left(1.2 \times 10^{-10} \mathrm{~g} / \mathrm{mL}\right)$ is limited due to the high background and only one ECL molecule is attached directly to each peptide.

The elaboration of ECL biosensors is probably one of the most promising ways to solve some of the problems concerning sensitivity, speediness, and stability. And much effort has been devoted to improve the sensitivity of ECL biosensors, such as employment of the nanoparticles-based signal amplification strategy. Nanoparticles including carbon nanotube, metal nanoparticles were employed as the amplification platform for the immobilization of molecular recognition elements [18], such as antibody [19], aptamer [20], carbohydrate [21], or peptide[22]. Gold nanoparticles (GNPs), with unique properties such as their fascinating electrocatalytic activity, large surface area, excellent conductivity, and stability, have been widely used in designing ECL biosenesors [23, 24]. Generally, the ECL biosensors utilize GNPs for the modification of the substrate electrodes, which provide large electrode area and also facilitate the electron transfer between the ECL signals and the electrodes, thus affording the possibility of the improvement of ECL performance. The unique properties of GNPs-modified electrode interfaces lead to novel ECL biosensors with high sensitivity and good stability in immunoassay [25], DNA bioassay [26], and glycan biosensor [27]. In an alternative way, GNPs can work as carriers of conventional ECL signals such as luminol [11] and ruthenium complex [28] and, thus, afford substantial ECL signal amplification. We developed an ECL immunoassay for the determination of human immunoglobulin $\mathrm{G}$ at gold nanoparticles-modified paraffin-impregnated graphite electrode [29], an ECL DNA biosensor at gold nanoparticles-modified gold electrode [30] and a signal off aptasensor for the determination of thrombin at gold nanoparticles-modified gold electrode [31] with high sensitivity.

The aim of this work is to develop a highly sensitive ECL peptide-based method for the determination of protein, on basis of the idea of encompassing gold nanoparticles as amplification platform and peptide as molecular recognition element. The principle scheme is demonstrated in Fig. 1. Two specific peptides including peptidel with a sequence of CFYSHSFHENWPS, in which a thiol-containing cysteine residue was incorporated at the end of the specific peptide to facilitate self-assembly onto the surface of gold, peptide 2 with a sequence of FYSHSFHENWPSK, in which a $\mathrm{NH}_{2}$ containing lysine residue was incorporated at the end of the peptide to covalently couple with ECL signal, were designed according to ref. [17] and employed as capture peptide and report peptide, respectively. The peptide 2 was labeled with ruthenium bis(2,2'-bipyridine) (2,2'-bipyridine-4,4'-dicarboxylic acid)- $N$-hydroxysuccinimide ester (Ru(bpy) ${ }_{2}$ (dcbpy)NHS) via acylation reaction through $\mathrm{NH}_{2}$-containing lysine at the end of the peptide to form the ECL probe Ru-peptide2. Gold nanoparticles were electrodeposited onto gold electrode and used as an amplification platform. The ECL peptide-based biosensor was fabricated by self-assembling the peptide 1 onto a gold nanoparticles-modified gold electrode surface through a thiol-containing cysteine at the end of the peptide1. When the biosensor reacted with target TnI, and then incubated with the ECL probe, a strong ECL response was electrochemically generated. In this paper, the characteristics of the ECL probe and the ECL peptide-based biosensor and the analytical performance for $\mathrm{TnI}$ are presented.

\section{Experimental}

Reagents and apparatus

Two peptides chemically synthesized, including peptide1 with a sequence of CFYSHSFHENWPS (13 mer, MW $=1$, 640.77), peptide2 with a sequence of FYSHSFHENWPSK (13 mer, MW=1,665.80), were designed according to ref. [17] and purchased from Sinoasis Pharmaceuticals, Inc 
Fig. 1 Schematic representation of the ECL peptide-based biosensor for the determination of TnI

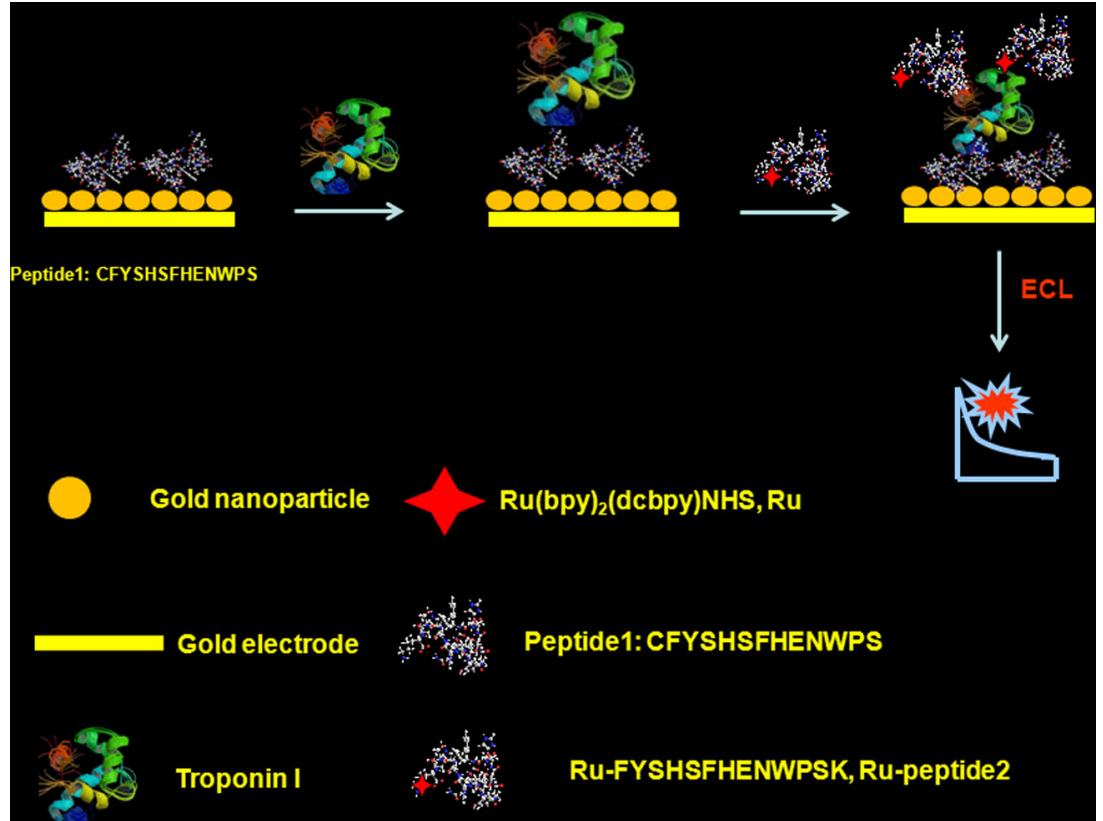

(China). Cardiac troponin I (TnI, human heart) was obtained from Abcam, Inc. (Cambridge, UK). Mercaptohexanol $(\mathrm{MCH}), \operatorname{Bis}\left(2,2^{\prime}\right.$-bipyridine)-4,4'-dicarboxybipyridineruthenium $\operatorname{di}(N$-succinimidyl ester) bis(hexafluorophosphate) $\left(\mathrm{Ru}(\mathrm{bpy})_{2}(\mathrm{dcbpy}-\mathrm{NHS})\left(\mathrm{PF}_{6}\right)_{2}\right.$, abbreviated as $\left.\mathrm{Ru}\right)$ and $\mathrm{HAuCl}_{4}$ were obtained from Sigma Aldrich (USA). Human alpha-fetoprotein (AFP) and prostate specific antigen (PSA) were obtained from Fitzgerald Industries International, Inc. (USA). Human immunoglobulin $\mathrm{G}(\mathrm{IgG})$ and bovine serum albumin (BSA) were obtained from Beijing Biosynthesis Biotechnology Co., Ltd. (China). Albumin chicken egg protein was obtained from Sino-American Biotechnology Co., Ltd. (China).

The serum samples were provided by Xianyang Central Hospital (China). Phosphate buffered saline (PBS) (0.1 M) consisted of $0.1 \mathrm{M} \mathrm{NaH}_{2} \mathrm{PO}_{4}, 0.1 \mathrm{M} \mathrm{Na}_{2} \mathrm{HPO}_{4}$, and $0.1 \mathrm{M}$ $\mathrm{KCl}(\mathrm{pH}$ 7.4). The other reagents used in this work were of analytical grade and directly used without additional purification. Millipore Milli-Q water $(18.2 \mathrm{M} \Omega \mathrm{cm})$ was used to prepare all solutions.

ECL measurements were performed with a MPI-A ECL detector (Xi'an Remax Electronics, China). A commercial cylindroid glass cell was used as an ECL cell, which contained a conventional three-electrode system that consisted of a gold electrode $(2.0 \mathrm{~mm}$ diameter) as the working electrode, a platinum wire as the counter electrode, and an $\mathrm{Ag} / \mathrm{AgCl}$ (saturated $\mathrm{KCl}$ ) as the reference electrode. ECL emissions were detected with a photomultiplier tube (PMT) that was biased at $-900 \mathrm{~V}$ unless otherwise stated. Electrochemical experiments were performed with a $\mathrm{CHI} 660$ electrochemical workstation (Chenhua Instruments Co., China).
Preparation of ECL probes

The ECL probe, Ru(bpy $)_{2}$ (dcbpy-NHS) $\left(\mathrm{PF}_{6}\right)_{2}$ labeled peptide2 (Ru-peptide2), were synthesized according to literatures with some modifications [14, 15]. Briefly, $1 \mathrm{mg}$ of the peptide $2(0.0006 \mathrm{~mol})$ was dissolved in $0.5 \mathrm{~mL}$ of $0.1 \mathrm{M}$ phosphate buffer (PB) consisted of $0.1 \mathrm{M} \mathrm{NaH}_{2} \mathrm{PO}_{4}$ and $0.1 \mathrm{M}$ $\mathrm{Na}_{2} \mathrm{HPO}_{4}$ (pH 7.4). Then, a $25 \mu \mathrm{L} 0.02 \mathrm{M} \mathrm{Ru}(\text { bpy) })_{2}$ (dcbpy$\mathrm{NHS})\left(\mathrm{PF}_{6}\right)_{2}$ was added into $0.5 \mathrm{~mL}$ 10-diluted peptide2 solution under stirring, followed by an overnight incubation. The Ru-peptide2 was purified by dialysis for $12 \mathrm{~h}$ at $4{ }^{\circ} \mathrm{C}$ using MD34-2 Da molecular weight cutoff membrane with $0.1 \mathrm{M}$ PBS ( $\mathrm{pH}$ 7.4). The concentration of Ru-peptide2 solution was estimated to be $1.5 \times 10^{-5} \mathrm{M}$, on the basis of UV absorbance of $\mathrm{Ru}(\mathrm{bpy})_{2}(\mathrm{dcbpy}-\mathrm{NHS})\left(\mathrm{PF}_{6}\right)_{2}$ at $457 \mathrm{~nm}$ $[32,33]$.

Fabrication of the ECL peptide-based biosensor

The biosensor was fabricated by two steps including an electrochemical deposition step and an immobilization step. The procedure for the deposition of gold nanoparticles onto gold electrode was adapted from the ref. [34]. Prior to the experiment, the gold electrode was polished with $0.3 \mu \mathrm{m}$ alumina slurry and then ultra-sonicated in water for $5 \mathrm{~min}$. The polished gold electrode was immersed in $0.1 \mathrm{M} \mathrm{HClO}_{4}$ containing $0.1 \% \mathrm{HAuCl}_{4}$, which was degassed with $\mathrm{N}_{2}$ stream for at least $20 \mathrm{~min}$ before the electrochemical deposition. Gold nanoparticles were electrodeposited on the gold electrode by holding a constant potential of $+1.1 \mathrm{~V}$ (vs. $\mathrm{Ag} / \mathrm{AgCl}$, sat. $\mathrm{KCl}$ ) for $60 \mathrm{~s}$ and then a constant potential of 
$-0.1 \mathrm{~V}$ for $5 \min$ in $0.1 \mathrm{M} \mathrm{HClO}_{4}$ containing $0.1 \% \mathrm{HAuCl}_{4}$ to form gold nanoparticles-modified gold electrode (GNPs/ $\mathrm{Au}$ electrode).

The peptide1 (CFYSHSFHENWPS) was immobilized onto the surface of GNPs/Au electrode by dipping the electrode into $11.3 \mu \mathrm{M}$ peptide 1 solution for $2 \mathrm{~h}$ at $4{ }^{\circ} \mathrm{C}$ and rinsing with $10 \mathrm{mM} P B(\mathrm{pH} 7.4)$ to remove the unbinding peptide1. The peptide-modified GNPs/Au electrode was then immersed in $1 \mathrm{mM}$ mercaptohexanol solution for $30 \mathrm{~min}$ to block the uncovered surface of the electrode. The resulting electrode (peptide1/GNPs/Au electrode) was washed with water and used as the ECL peptide-based biosensor.

\section{ECL measurement}

The ECL peptide-based biosensor fabricated was immersed in $100 \mu \mathrm{L} 10 \mathrm{mM}$ PBS (pH 7.4) containing different concentrations of TnI for $1 \mathrm{~h}$ at room temperature. Then, the resulting ECL peptide-based biosensor was dipped into $100 \mu \mathrm{L}$ of $1.5 \mu \mathrm{M}$ ECL probe for $1 \mathrm{~h}$ at room temperature. After each incubation, the biosensor was rinsed thoroughly with $10 \mathrm{mM}$ PBS ( $\mathrm{pH}$ 7.4) to remove adsorption components. The ECL measurement was performed at a constant potential of $+0.90 \mathrm{~V}$ in $2.0 \mathrm{~mL}$ of $0.10 \mathrm{M}$ PBS (pH 7.4) containing $50 \mathrm{mM}$ tripropylamine (TPA). The concentration of TnI was quantified by an increased ECL intensity $\left(\Delta I=I_{\mathrm{S}}-I_{0}\right)$, where $I_{\mathrm{S}}$ was the ECL intensity of ECL peptide-based biosensor reacted with $\mathrm{TnI}$ and $I_{0}$ was the blank ECL intensity of ECL peptide-based biosensor. All experiments were carried out at room temperature.

\section{Results and discussion}

\section{Characterization of the ECL probe}

The ECL probe Ru-peptide2 synthesized was characterized by UV-vis spectroscopy and ECL. Figure $2 \mathrm{a}$ shows UV-vis spectra of the peptide2, Ru(bpy) ${ }_{2}$ (dcbpy)NHS and Ru-peptide2. The characteristic peaks of peptide2 appear at $263 \mathrm{~nm}$ (line a) and the characteristic peaks of $\mathrm{Ru}$ (bpy) ${ }_{2}$ (dcbpy)NHS appear at 201, 276, and $457 \mathrm{~nm}$ (line b). The characteristic absorption peaks of Ru-peptide2 appear at 207, 276, and $457 \mathrm{~nm}$ (line c), corresponding to the characteristic peaks of $\mathrm{Ru}(\mathrm{bpy})_{2}$ (dcbpy)NHS at 450, 276, $207 \mathrm{~nm}$ and peptide at $263 \mathrm{~nm}$, respectively. This indicates that $\mathrm{Ru}(\mathrm{bpy})_{2}$ (dcbpy)NHS is labeled to the peptide2.

Figure $2 \mathrm{~b}$ shows ECL intensity-potential profiles of $\mathrm{Ru}(\mathrm{bpy})_{2}(\mathrm{dcbpy}-\mathrm{NHS})\left(\mathrm{PF}_{6}\right)_{2}$ (line a) and Ru-peptide2 (line b) in $0.10 \mathrm{M}$ PBS containing $50 \mathrm{mM}$ TPA. From Fig. $2 b$, it can be seen that both ECL peaks appear at near + $900 \mathrm{mV}$, which is similar with that $(+900 \mathrm{mV})$ in ref. [35], a
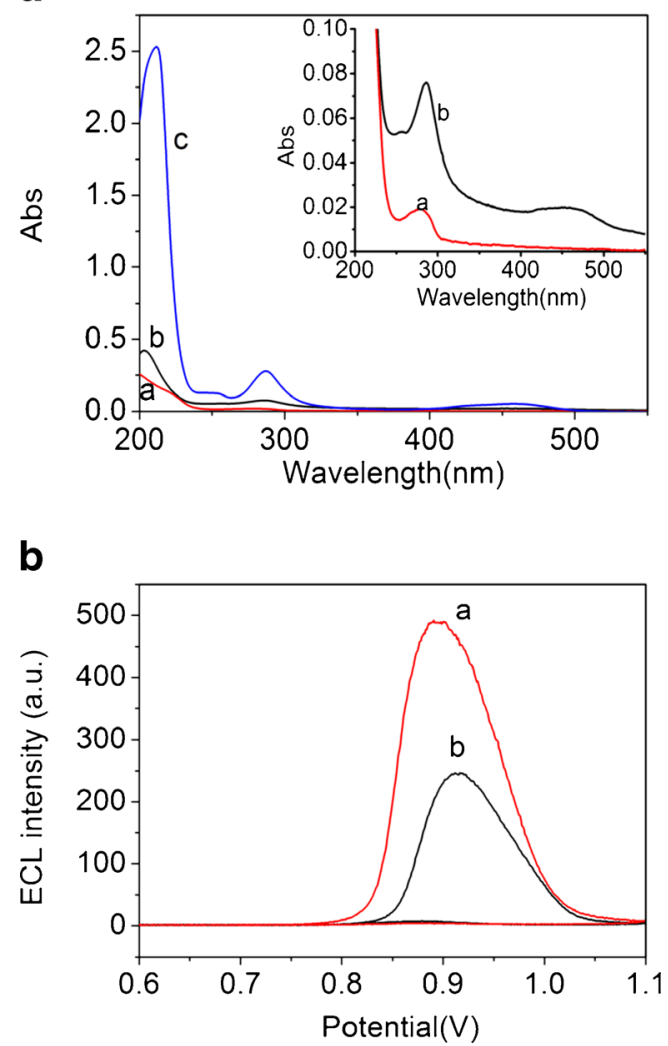

Fig. 2 a UV-vis spectra of peptide $(a), \mathrm{Ru}(\mathrm{bpy})_{2}(\mathrm{dcbpy}-\mathrm{NHS})\left(\mathrm{PF}_{6}\right)_{2}$ (b) and Ru-peptide2 (c). b ECL intensity-potential profiles of $1.5 \times$ $10^{-7} \mathrm{M} \mathrm{Ru}(\mathrm{bpy})_{2}(\mathrm{dcbpy}-\mathrm{NHS})\left(\mathrm{PF}_{6}\right)_{2}(a)$ and $1.5 \times 10^{-7} \mathrm{M}$ Ru-peptide2 (b) in $0.10 \mathrm{M}$ PBS (pH 7.4) containing $50 \mathrm{mM}$ TPA. Scan rate, $50 \mathrm{mV} / \mathrm{s}$

indicating that the ECL behavior of Ru-peptide2 is similar to that of $\mathrm{Ru}(\mathrm{bpy})_{2}$ (dcbpy)NHS and Ru(bpy) $)_{2}$ (dcbpy)NHS is attached to peptide2.

Feasibility of ECL peptide-based biosensor for the determination of $\mathrm{TnI}$

The fabrication process of the peptide-based biosensor was characterized by cyclic voltammetry in the presence of the ferri/ferrocyanide redox couple as redox probe (see Fig. S1 A in supporting information). As expected, $\mathrm{K}_{3}\left[\mathrm{Fe}(\mathrm{CN})_{6}\right] /$ $\mathrm{K}_{4}\left[\mathrm{Fe}(\mathrm{CN})_{6}\right]$ showed the reversible behavior on a bare gold electrode and on a gold nanoparticles-modified electrode with a peak-to-peak separation $\Delta E_{\mathrm{p}}$ of $76 \mathrm{mV}$ (Fig. S1 A, line ab). After gold nanoparticles were electrodeposited onto gold electrode, the peak current increased from 23.89 to $29.21 \mu \mathrm{A}$ (Fig. S1 A, line b), ascribing to the increase of electrode surface area, which is confirmed by the CV results in $0.1 \mathrm{M}$ $\mathrm{H}_{2} \mathrm{SO}_{4}$ (Fig. S1 B). The immobilization of peptide1 on the surface of gold nanoparticles-modified gold electrode led to a significant increase in the peak-to-peak separation $\left(\Delta E_{\mathrm{p}}=\right.$ $143 \mathrm{mV}$ ) (Fig. S1 A, line c) and decrease of peak current $(21.22 \mu \mathrm{A})$, indicating that peptide1 is self-assembled on the 
electrode. This is mainly attributed to the fact that the peptide1 modified on the surface of the electrode prohibits the mass transfer of $\left[\mathrm{Fe}(\mathrm{CN})_{6}\right]^{3-/ 4-}$ from the solution to the surface of electrode. After reacted with TnI and Ru-peptide2, the peakto-peak separation further increased $\left(\Delta E_{\mathrm{p}}=196 \mathrm{mV}\right)$ and the peak current decreased to $17.22 \mu \mathrm{A}$ (Fig. S1A, line d). This indicates that the peptide is self-assembled onto the electrode surface and the sandwich conjugates is formed onto the surface electrode.

Figure 3 a shows the ECL intensity vs potential profiles of the ECL peptide-based biosensor reacted with $1.0 \times 10^{-11}$ and $1.0 \times 10^{-10} \mathrm{~g} / \mathrm{mL}$ TnI, respectively. Compared line a and line $\mathrm{b}$, it can be seen that the ECL peptide-based biosensor shows a low ECL signal (line a, 1,048) while the ECL peptide-based biosensor reacted with $1.0 \times 10^{-11} \mathrm{~g} / \mathrm{mL} \mathrm{TnI}$ displays a higher ECL signal (line b, 4,955) in $0.10 \mathrm{M}$ PBS (pH 7.4) containing $50 \mathrm{mM}$ TPA. Compared line $\mathrm{b}$ with line $\mathrm{c}$, it can be clearly observed that the ECL peak intensity increases from 4,955 to 8,648 as the concentration of $\mathrm{TnI}$ is elevated from $1.0 \times 10^{-11}$
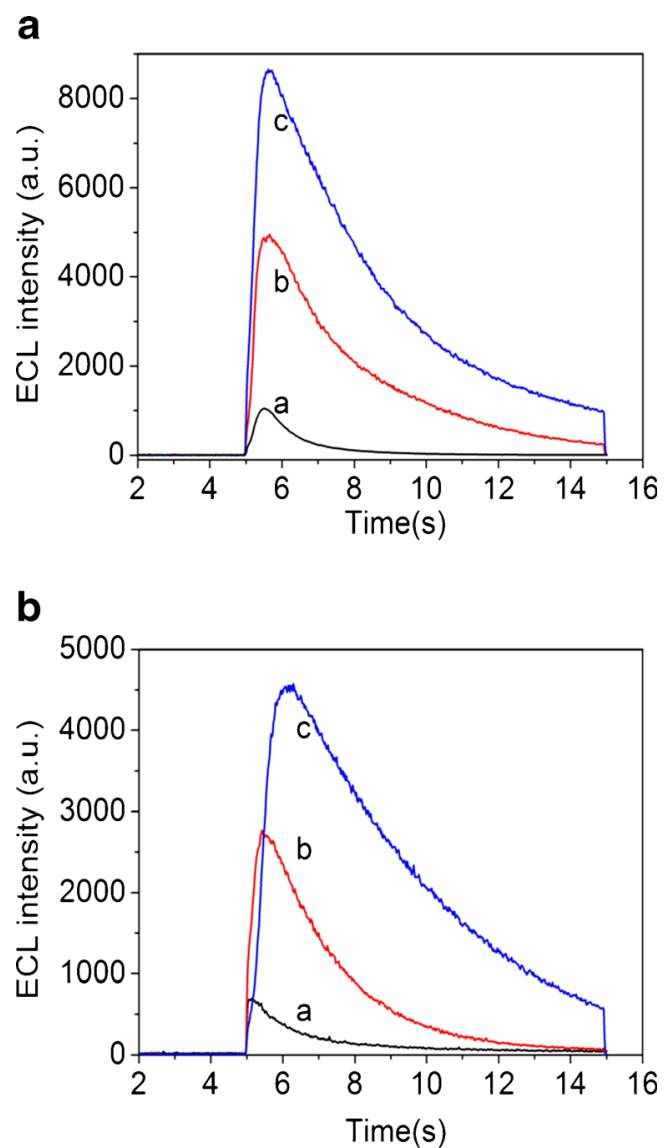

Fig. 3 ECL intensity-potential profiles of the ECL peptide-based biosensor fabricated on GNPs-modified gold electrode (a) and the ECL peptide-based biosensor fabricated on bare gold electrode (b) in $0.10 \mathrm{M}$ PBS (pH 7.4) containing $50 \mathrm{mM}$ TPA at a constant potential of $0.90 \mathrm{~V}$, before $(a)$ and after reaction with $1.0 \times 10^{-11} \mathrm{~g} / \mathrm{mL} \mathrm{TnI}(b)$ and $1.0 \times$ $10^{-10} \mathrm{~g} / \mathrm{mL} \mathrm{TnI}(c)$, respectively to $1.0 \times 10^{-10} \mathrm{~g} / \mathrm{mL}$. The results indicate that the ECL method is feasible for the determination of TnI.

In order to illustrate the function of gold nanoparticles, another kind of the peptide-based biosensor was fabricated by self-assembling peptide1 onto bare gold electrode surface through a thiol-containing cysteine at the end of the peptide 1 and evaluated according to the protocol described in experimental section. Figure 3b shows the ECL intensitypotential profiles of the ECL peptide-based biosensor employing gold electrode as platform for the determination of TnI. The ECL peptide-based biosensor shows a low ECL signal (line a, 697). The ECL intensity were 2,779 (line b) and 4,576 (line c) after reacting with $1.0 \times 10^{-11}$ and $1.0 \times 10^{-10} \mathrm{~g} / \mathrm{mL}$ TnI, respectively. Comparing Fig. 3a, b, the ECL intensity at the peptide1/GNPs/Au electrode was 1.5-1.9 times higher than that obtained at a peptide $1 / \mathrm{Au}$ electrodes at same condition. The packing density of the peptide 1 on the different electrodes surface is estimated on basis of the electrode surface area and the amount of peptide1. The amount of peptidel was related with the charge associated with the electrode desorption reaction arising from the one-electron reduction of peptide1 layer on gold surface according Faraday law [36]. The peptide densities at the bare electrode and gold nanoparticles-modified electrode were $3.58 \times 10^{-10}$ and $11.2 \times 10^{-10}$ molecules. $\mathrm{cm}^{-2}$, respectively, corresponding the effective electrode area of $0.037 \mathrm{~mm}^{2}$ for bare gold electrode and $0.05 \mathrm{~mm}^{2}$ for gold nanoparticles-modified gold electrode (as seen in supporting information Figure S2). The packing density of the peptide1 on gold nanoparticlesmodified electrode was 3.1-folds larger than that of the bare gold electrode. In summer, gold nanoparticles not only facilitate the electron transfer at the electrode interface and catalyze the ECL process of ruthenium complex/TPA system $[25,37]$, but also increase the interface area of the electrode to capture more molecular recognition element for recognition of targets, and then immobilize numerous signal-generating molecules. The signal enhancement of the gold nanoparticles for the ECL peptide-based biosensor designed is evident.

\section{Optimization of conditions}

The applied potential is an important parameter because it decides the sensitivity of the ECL peptide-based biosensors. The dependence of the ECL intensity of the ECL peptidebased biosensor on applied potential was checked for $1.0 \times$ $10^{-10} \mathrm{~g} / \mathrm{mL}$ TnI. Figure 4a shows that the ECL intensity increases when the applied potential is raised from +0.8 to + $0.9 \mathrm{~V}$ and reaches a maximum at $+0.9 \mathrm{~V}$. Therefore, the constant potential of $+0.9 \mathrm{~V}$ was chosen in following experiments.

Figure $4 \mathrm{~b}$ shows the effect of binding time between the peptide 1 and TnI on the ECL intensity. The ECL intensity sharply increases with increasing binding time from 20 to $60 \mathrm{~min}$ and reaches a maximum at about $60 \mathrm{~min}$. When further 

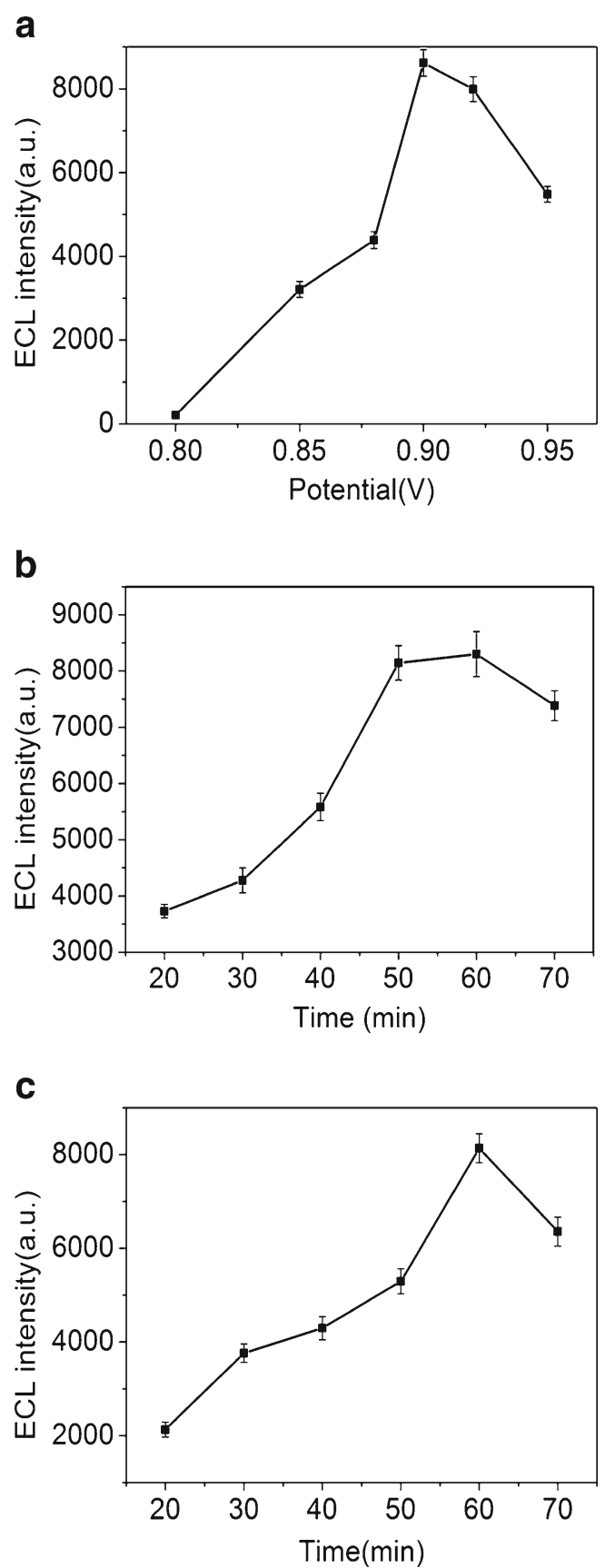

Fig. 4 a Effect of applied potential on the ECL intensity; $\mathbf{b}$ effect of binding time between peptide 1 and $1.0 \times 10^{-10} \mathrm{~g} / \mathrm{mL}$ TnI on the ECL intensity. c Effect of binding time between $1.0 \times 10^{-10} \mathrm{~g} / \mathrm{mL}$ TnI and Ru-peptide 2 on the ECL intensity. In $0.10 \mathrm{M}$ PBS (pH 7.4) containing $50 \mathrm{mM}$ TPA

increasing the binding time, the ECL intensity decreases slightly. This is attributed to steric and electrostatic hindrance arising from the more tightly packed $\mathrm{TnI}$ monolayer. Figure $4 \mathrm{c}$ demonstrates the effect of the binding time between TnI and the Ru-peptide2 on the ECL intensity. The results showed that the ECL intensity sharply increased with increasing binding time from 20 to $60 \mathrm{~min}$, and then, reached a maximum at $60 \mathrm{~min}$. Considering both of the binding time between

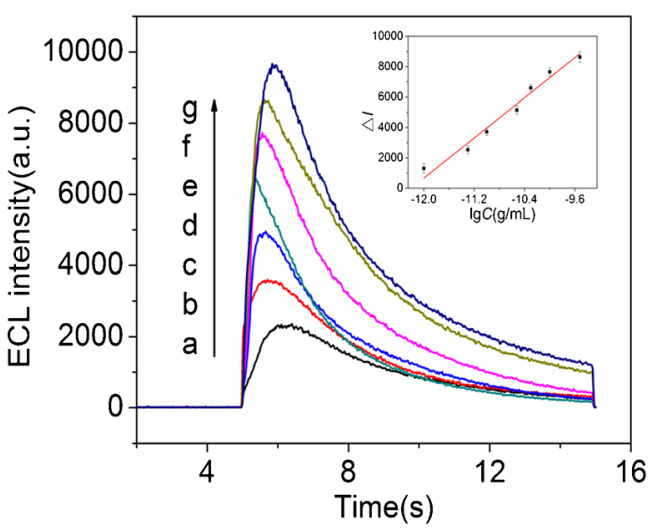

Fig. 5 ECL intensity vs time profiles for different concentrations of TnI in $0.10 \mathrm{M}$ PBS $(\mathrm{pH}=7.4)$ containing $50 \mathrm{mM}$ TPA: a $1.0 \times 10^{-12} \mathrm{~g} / \mathrm{mL}, \mathbf{b}$ $5.0 \times 10^{-12} \mathrm{~g} / \mathrm{mL}, \mathbf{c} 1.0 \times 10^{-11} \mathrm{~g} / \mathrm{mL}, \mathbf{d} 3.0 \times 10^{-11} \mathrm{~g} / \mathrm{mL}, \mathbf{e} 5.0 \times 10^{-11} \mathrm{~g} / \mathrm{mL}$, f $1.0 \times 10^{-10} \mathrm{~g} / \mathrm{mL}$, g $3.0 \times 10^{-10} \mathrm{~g} / \mathrm{mL}$. Insert, calibration curve of TnI. Experimental conditions, applied potential, $0.90 \mathrm{~V}$; binding time, $60 \mathrm{~min}$; $0.10 \mathrm{M}$ PBS (pH 7.4) containing $50 \mathrm{mM}$ TPA

peptide 1 and TnI with the binding time of Ru-peptide 2 and TnI, we chosen $60 \mathrm{~min}$ as binding time for both of incubation process in following experiments.

\section{Analytical performance of ECL peptide-based biosensor}

The quantitative behavior of the ECL peptide-based biosensor fabricated was assessed under the optimized conditions. Figure 5 shows the ECL intensity vs time profiles of the ECL peptide-based biosensors for the determination of TnI. The ECL intensity increases with an increase of the concentration of TnI. The increased ECL intensity has a linear relationship with the logarithm of the concentration of $\mathrm{TnI}$ in the range from $1.0 \times 10^{-12}$ to $3.0 \times 10^{-10} \mathrm{~g} / \mathrm{mL}$. The linear regression equation is $\Delta I=3,303 \lg C+40,305$ (unit of $C$ is in gram per milliliter) and the correlation coefficient was 0.9662 . The relative standard derivation for $1.0 \times 10^{-11} \mathrm{~g} / \mathrm{mL}$ TnI was $2.8 \%$. The detection limit (DL) is $0.4 \mathrm{pg} / \mathrm{mL}$, which is 300-fold lower than that obtained by homogenous ECL method using Ru-labeled peptide [14] and 3-fold lower than that obtained by homogenous ECL method using Ru-

Table 1 Analytical results of $\mathrm{TnI}$ in clinical serum samples

\begin{tabular}{lllc}
\hline $\begin{array}{l}\text { Sample } \\
\text { number }\end{array}$ & $\begin{array}{l}\text { CL method } \\
(\mathrm{ng} / \mathrm{mL})^{\mathrm{a}}\end{array}$ & $\begin{array}{l}\text { This method }(n=3, \\
P=0.9, \mathrm{ng} / \mathrm{mL})^{\mathrm{b}}\end{array}$ & $\begin{array}{l}\text { Relative } \\
\text { error }(\%)\end{array}$ \\
\hline 1 & 5.09 & $4.85 \pm 0.70$ & -4.7 \\
2 & 2.94 & $2.95 \pm 0.06$ & 0.4 \\
3 & 1.02 & $1.01 \pm 0.01$ & -1.0 \\
\hline
\end{tabular}

${ }^{\mathrm{a}}$ The CL results of TnI in serum samples from clinical reports provided by Xianyang Central Hospital.

${ }^{\mathrm{b}}$ Confidence interval 
encapsulated liposomes labeled peptide as the ECL probe in our previous report [15]. The employment of gold nanoparticles as amplification platform and peptide as molecular recognition element to improve the sensitivity is evident.

The evaluation of the selectivity of the ECL peptide-based biosensor was performed by examining $1.0 \times 10^{-10} \mathrm{~g} / \mathrm{mL}$ $\left(8.3 \times 10^{-11} \mathrm{M}\right) \mathrm{TnI}$ or $1.5 \times 10^{-7} \mathrm{M}$ other proteins including AFP, PSA, albumin chicken egg protein and IgG, respectively. A significant increase in ECL intensity $(72.5 \%)$ by the interaction with $\mathrm{TnI}$ was observed (as shown in Fig. S3). On the other hand, very slight increases in ECL intensity were found for the other tested proteins including AFP (7.2\%), PSA (6.3\%), albumin chicken egg protein ( $8.4 \%)$, and $\operatorname{IgG}$ (7.9\%), respectively. This indicates that the developed strategy has good selectivity for TnI.

\section{Sample analysis}

To evaluate a potential application of the ECL peptide-based biosensor, serum samples obtained from Xianyang Central Hospital were assayed using the proposed method in this work. The results are presented in Table 1. The obtained results show an acceptable agreement with the data provided by Xianyang Central Hospital (China) using a standard chemiluminescence (CL) method with an Abbott Immunoanalyzer (Abbott Axsym, i1000, USA), no statistical significance $(P$ value $=0.9)$ is obtained between the result using the ECL method in this work and that CL method, therefore, signifying the feasibility of the ECL method in clinical sample.

\section{Conclusion}

In this work, we fabricated a high sensitive electrogenerated chemiluminescence peptide-based biosensor for the detection of TnI. Great signal amplification was achieved with an extremely low detection limit of $0.4 \mathrm{pg} / \mathrm{mL}$ attributed to the combination of gold nanoparticles as amplification platform and peptide as molecular recognition element. The strategy presented in this study could be easily extended to the detection of other biomarkers.

Acknowledgements We gratefully acknowledge the financial support from The National Science Foundation of China (nos. 21375084, 21275095, 21027007) and the Natural Science Basic Research Plan in Shaanxi Province of China (no. 2013KJXX-73) and the Fundamental Research Funds for the Central Universities (no.GK261001185).

Open Access This article is distributed under the terms of the Creative Commons Attribution License which permits any use, distribution, and reproduction in any medium, provided the original author(s) and the source are credited.

\section{References}

1. Qureshi A, Gurbuz Y, Niazi JH (2012) Biosensors for cardiac biomarkers detection: a review. Sens Actuators B 171-172: $62-76$

2. McDonnell B, Hearty S, Leonard P, O'Kennedy R (2009) Cardiac biomarkers and the case for point-of-care testing. Clin Biochem 42: $549-561$

3. Wu J, Cropek DM, West AC, Banta S (2010) Development of a troponin I biosensor using a peptide obtained through phage display. Anal Chem 82:8235-8243

4. Akanda MR, Aziz MA, Jo K, Tamilavan V, Hyun MH, Kim S, Yang H (2011) Optimization of phosphatase- and redox cycling-based immunosensors and its application to ultrasensitive detection of troponin I. Anal Chem 83:3926-3933

5. Guo H, Yang D, Gu C, Bian Z, He N, Zhang J (2005) Development of a Low density colorimetric protein array for cardiac troponin I detection. J Nanosci Nanotechnol 5:2161-2166

6. Nandhikonda P, Heagy MD (2011) An abiotic fluorescent probe for cardiac troponin I. J Am Chem Soc 133:14972-14974

7. Rusling JR, Kumar CV, Gutkind JS, Patel V (2010) Analyst 135: 2496-2511

8. Cho IH, Paek EH, Kim YK, Kim JH, Paek SH (2009) Chemiluminometric enzyme-linked immunosorbent assays (ELISA)-on-a-chip biosensor based on cross-flow chromatography. Anal Chim Acta 632:247-255

9. $\mathrm{Hu} \mathrm{L}, \mathrm{Xu}$ G (2010) Applications and trends in electrochemiluminescence. Chem Soc Rev 39:3275-3304

10. Miao W (2008) Electrogenerated chemiluminescence and its biorelated applications. Chem Rev 108:2506-2553

11. Li F, Yu Y, Cui H, Yang D, Bian Z (2013) Label-free electrochemiluminescence immunosensor for cardiac troponin I using luminol functionalized gold nanoparticles as a sensing platform. Analyst 138(6):1844-1850

12. Shen W, Tian D, Cui H, Yang D, Bian Z (2011) Nanoparticle-based electrochemiluminescence immunosensor with enhanced sensitivity for cardiac troponin I using $N$-(aminobutyl)- $N$-(ethylisoluminol)functionalized gold nanoparticles as labels. Biosens Bioelectron 27: $18-24$

13. Sun D, Hamlin D, Butterfield A, Watson DE, Smith HW (2010) Electrochemiluminescent immunoassay for rat skeletal troponin I (Tnni2) in serum. J Pharmacol Toxicol Methods 61:52-58

14. Wang C, Qi H, Qiu X, Gao Q, Zhang C (2012) Homogeneous electrogenerated chemiluminescence peptide-based method for determination of troponin I. Anal Methods 4:2469-2474

15. Qi H, Qiu X, Xie D, Ling C, Gao Q, Zhang C (2013) Ultrasensitive electrogenerated chemiluminescence peptide-based method for the determination of cardiac troponin I incorporating amplification of signal reagent-rncapsulated liposomes. Anal Chem 85:3886-3894

16. Petrenko VA, Vodyanoy VJ (2003) Phage display for detection of biological threat agents. J Microbiol Methods 53:253-262

17. Park JP, Cropek DM, Banta S (2010) High affinity peptides for the recognition of the heart disease biomarker troponin I identified using phage display. Biotechnol Bioeng 105:678-686

18. Li Y, Schluesener HJ, Xu S (2010) Gold nanoparticle-based biosensors. Gold Bull 43:29-41

19. Jiang X, Chai Y, Yuan R, Cao Y, Chen Y, Wang H, Gan X (2013) An ultrasensitive luminol cathodic electrochemiluminescence immunosensor based on glucose oxidase and nanocomposites: graphene-carbon nanotubes and gold-platinum alloy. Anal Chim Acta 783:49-55

20. Deng S, Cheng L, Lei J, Cheng Y, Huang Y, Ju H (2013) Label-free electrochemiluminescent detection of DNA by hybridization with a molecular beacon to form hemin/G-quadruplex architecture for signal inhibition. Nanoscale 5:5435-41 
21. Han E, Ding L, Jin S, Ju H (2011) Electrochemiluminescent biosensing of carbohydrate-functionalized CdS nanocomposites for in situ label-free analysis of cell surface carbohydrate. Biosens Bioelectron 26:2500-2555

22. Liu L, Zhao F, Ma F, Zhang L, Yang S, Xia N (2013) Electrochemical detection of $\beta$-amyloid peptides on electrode covered with $\mathrm{N}$ terminus-specific antibody based on electrocatalytic $\mathrm{O}_{2}$ reduction by $\mathrm{A} \beta(1-16)$-heme-modified gold nanoparticles. Biosens Bioelectron 49:231-235

23. Qi H, Peng Y, Gao Q, Zhang C (2009) Applications of nanomaterials in electrogenerated chemiluminescence biosensors. Sensors 9: 674-695

24. Cao X, Ye Y, Liu S (2011) Gold nanoparticle-based signal amplification for biosensing. Anal Biochem 417:1-16

25. Yin XB, Qi B, Sun X, Yang X, Wang E (2005) 4(Dimethylamino)butyric acid labeling for electrochemiluminescence detection of biological substances by increasing sensitivity with gold nanoparticle amplification. Anal Chem 77:3525-3530

26. Yao W, Wang L, Wang H, Zhang X, Li L, Zhang N, Pan L, Xing N (2013) An electrochemiluminescent DNA sensor based on nano-gold enhancement and ferrocene quenching. Biosens Bioelectron 40:356-361

27. Chen Z, Liu Y, Wang Y, Zhao X, Li J (2013) Dynamic evaluation of cell surface $N$-glycan expression via an electrogenerated chemiluminescence biosensor based on concanavalin A-integrating gold-nanoparticle-modified $\mathrm{Ru}(\mathrm{bpy})_{3}{ }^{2+}$-doped silica nanoprobe. Anal Chem 85:4431-4438

28. Duan R, Zhou X, Xing D (2010) Electrochemiluminescence biobarcode method based on cysteamine-gold nanoparticle conjugates. Anal Chem 82:3099-3103

29. Qi H, Zhang Y, Peng Y, Zhang C (2008) Homogenous electrogenerated chemiluminescence immunoassay for human immunoglobulin G using $N$-(aminobutyl)- $N$-ethylisoluminol as luminescence label at gold nanoparticles modified paraffinimpregnated graphite electrode. Talanta 75:684-690

30. Li Y, Qi H, Yang J, Zhang C (2009) Detection of DNA immobilized on bare gold electrodes and gold nanoparticle-modified electrodes via electrogenerated chemiluminescence using a ruthenium complex as a tag. Microchim Acta 164:69-76

31. Li Y, Qi H, Gao Q, Yang J, Zhang C (2010) Nanomaterial-amplified "signal off/on" electrogenerated chemiluminescence aptasensors for the detection of thrombin. Biosens Bioelectron 26:754759

32. Shimidzu T, Iyoda T, Izaki K (1985) Photoelectrochemical properties of bis(2,2'-bipyridlne) (4,4'-dlcarboxy-2,2'-bipyrldlne)ruthenlum( II) chloride. J Phys Chem 89:642-645

33. Li Y, Qi H, Peng Y, Yang J, Zhang C (2007) Electrogenerated chemiluminescence aptamer-based biosensor for the determination of cocaine. Electrochem Commun 9:2571-2575

34. Martín H, Carro P, Creus AH, Gonzá lez S, Andreasen G, Salvarezza RC, Arvia AJ (2000) The influence of adsorbates on the growth mode of gold islands electrodeposited on the basal plane of graphite. Langmuir 16:2915-2923

35. Zhang J, Qi H, Li Y, Yang J, Gao Q, Zhang C (2008) Electrogenerated chemiluminescence DNA biosensor based on hairpin DNA probe labeled with ruthenium complex. Anal Chem 80:2888-2894

36. El-Deab1 MS, Ohsaka T (2004) Molecular-level design of binary self-assembled monolayers on polycrystalline gold electrodes. Electrochim Acta 49:2189-2194

37. Chen Z, Zu Y (2007) Gold nanoparticle-modified ITO electrode for electrogenerated chemiluminescence: well-preserved transparency and highly enhanced activity. Langmuir 23: $11387-11390$ 